\title{
Surgical treatment of congenital coronary artery fistula
}

\author{
STANLEY JOHN, W JOHN PERIANAYAGAM, S MURALIDHARAN, V NANDAKUMAR, \\ RUTH MANSFIELD, S KRISHNASWAMY, I P SUKUMAR, AND GEORGE CHERIAN
}

From the Departments of Cardiothoracic Surgery, Anaesthesia, and Cardiology, Christian Medical College Hospital, Vellore, India

ABSTRACT Six patients with congenital coronary artery fistula underwent successful corrective surgery. Precise diagnosis was established either by retrograde aortography or more recently by selective arteriography. The left coronary artery was involved in four and the right in two cases. The fistula communicated with the right ventricle in three and the right atrium in three subjects. The operative approach is dictated by the site of entry of the vessel into the cardiac chamber. The use of cardiopulmonary bypass for intracardiac repair allows accurate closure of the fistula thereby reducing the chances of recurrence. A follow-up of one to seven years showed that all patients are asymptomatic and leading normal lives.

In coronary arteriovenous fistula there is an abnormal communication of one of the coronary arteries or one or more of their branches with a chamber of the heart, pulmonary artery, superior vena cava, inferior vena cava, or coronary sinus. The purpose of this report is to summarise our experience with six subjects in whom a coronary artery fistula opened into a chamber of the right heart.

\section{Patients and methods}

Over a 10-year period from 1970 to 1979,10 patients with a diagnosis of coronary artery fistula were seen at the departments of cardiothoracic surgery and cardiology of the Christian Medical College Hospital, Vellore, India. Six of these underwent corrective surgery and they form the basis for this report. We have not included in this series patients with anomalous origin of the left coronary artery from the pulmonary artery.

The youngest subject was 8 and the oldest 23 years of age. There were four males and two females.

One subject was completely asymptomatic and his murmur was detected on a routine examination after a febrile episode. In a boy of 9 years, frequent episodes of migraine prompted cardiac

Address for reprint requests: Professor Stanley John, Department of Cardiothoracic Surgery, CMC Hospital, Vellore-632 004, India. assessment which revealed the diagnosis. Slight exertional dyspnoea and effort intolerance were seen in three patients. Left-sided chest pain was complained of by two subjects but in neither was the pain suggestive of angina pectoris. Frequent respiratory infections were seen in two. Growth, development, and physical aprearance was normal in all. A collapsing pulse was seen in five of the six patients. The jugular venous pressure was not raised even in those subjects whose fistula opened into the right atrium. A palpable thrill with a continuous murmur was the hallmark on examination and was clearly evident in each instance. It was atypical in location and was related to the site of the fistula-over the apex in one, and in the third interspace along the left sternal border in the remaining two subjects.

Chest radiographs demonstrated moderate cardiomegaly and pulmonary plethora and, the electrocardiogram showed voltage criteria of left ventricular hypertrophy in all. In neither patient with left-sided chest pain was there any corroborative evidence of myocardial ischaemia either at rest or during exercise.

Cardiac catheterisation revealed an increase in oxygen saturation in the right atrium in three and the right ventricle in two subjects. In the sixth patient who had a dilated right coronary artery opening into the right ventricular outflow tract, the shunt was too small to be detected by standard 
Table

\begin{tabular}{|c|c|c|c|c|c|c|}
\hline Case & $\begin{array}{l}\text { Age } \\
(y r)\end{array}$ & Sex & Vessel involved & Termination & Surgery & Result \\
\hline 1 & 16 & $\mathbf{F}$ & Right coronary artery & $\begin{array}{l}\text { Right ventricular } \\
\text { outflow tract }\end{array}$ & $\begin{array}{l}\text { Cardiopulmonary bypass } \\
\text { External terminal ligation } \\
\text { clamping fistula-15 minutes }\end{array}$ & $\begin{array}{l}\text { No fistula in postoperative } \\
\text { angio six months later }\end{array}$ \\
\hline 2 & 18 & $\mathbf{F}$ & $\begin{array}{l}\text { Sino-atrial nodal branch } \\
\text { of left coronary artery }\end{array}$ & Right atrium & $\begin{array}{l}\text { Cardiopulmonary bypass } \\
\text { intracardiac closure through } \\
\text { right atriotomy }\end{array}$ & $\begin{array}{l}\text { No fistula in postoperative } \\
\text { angio } 15 \text { months later }\end{array}$ \\
\hline 3 & 23 & $\mathbf{M}$ & $\begin{array}{l}\text { Branch of circumflex } \\
\text { artery }\end{array}$ & Right atrium & $\begin{array}{l}\text { Cardiopulmonary bypass } \\
\text { intracardiac closure tnrough } \\
\text { right atriotomy }\end{array}$ & $\begin{array}{l}\text { No fistula in postoperative } \\
\text { angio nine months later }\end{array}$ \\
\hline 4 & 14 & $\mathbf{M}$ & $\begin{array}{l}\text { Left anterior descending } \\
\text { artery }\end{array}$ & Right ventricular apex & $\begin{array}{l}\text { Cardiopulmonary bypass } \\
\text { intracardiac closure through } \\
\text { right ventriculotomy }\end{array}$ & $\begin{array}{l}\text { Excellent-leading normal } \\
\text { life }\end{array}$ \\
\hline 5 & 8 & $\mathbf{M}$ & Right coronary artery & $\begin{array}{l}\text { Right ventricular outflow } \\
\text { tract }\end{array}$ & $\begin{array}{l}\text { Cardiopulmonary bypass } \\
\text { intracardiac closure through } \\
\text { right ventriculotomy }\end{array}$ & $\begin{array}{l}\text { Excellent-leading normal } \\
\text { life }\end{array}$ \\
\hline 6 & 9 & $\mathbf{M}$ & $\begin{array}{l}\text { Sino-atrial nodal branch } \\
\text { of left coronary artery }\end{array}$ & Right atrium & $\begin{array}{l}\text { Cardiopulmonary bypass } \\
\text { intracardiac closure through } \\
\text { right atrium }\end{array}$ & $\begin{array}{l}\text { Excellent-leading normal } \\
\text { life }\end{array}$ \\
\hline
\end{tabular}

means (table). Only one patient had a left to right shunt greater than $2: 1$.

Precise location of the site of entry into the right heart necessitates selective coronary arteriography. However, we were able to accomplish this

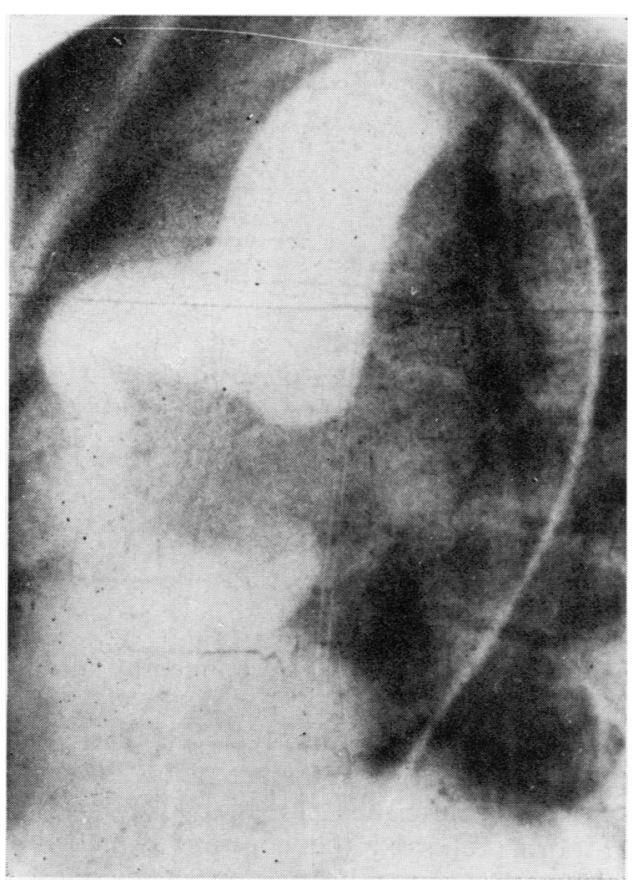

Fig 1 Aortogram with left anterior oblique view depicting right coronary artery fistula draining into right ventricle. in only two subjects and carried out aortography early in our series. The fistula originated from the right coronary artery in two and from the left coronary artery or its branches in the remaining four. The point of communication was into the right ventricle in three and into the right atrium in three subjects.

Correction was accomplished with the aid of cardiopulmonary bypass. In the first patient in our series, a large right coronary artery entered the right ventricular outflow tract (fig 1). In two subjects (table, patients 2 and 6) a large branch from the left coronary artery-the sinus node artery opened into the right atrium rather posteriorly near the confluence of the superior vena cava and atrial septum. Its termination was an aneurysmal dilatation $2 \times 2 \mathrm{~cm}$. In another patient, the circumflex branch of the left coronary artery traversed behind the aorta over the upper border of the left atrium and emptied into the right atrium near the superior vena cavo-atrial junction. The fourth patient showed an almost aneurysmal left anterior descending artery emptying into the apex of the right ventricle (fig 2). In another patient, we found a dilated right coronary artery opening into the right ventricular outflow tract.

Intracardiac obliteration of the fistulous channel was achieved in all cases. However, in one subject, external terminal ligation was carried out after clamping the fistula for 15 minutes had not caused any myocardial ischaemia. Furthermore, the right ventricle was opened to ensure that there was no additional communication within the chamber. Intracardiac closure in the remaining five subjects involved right atriotomy in three and 

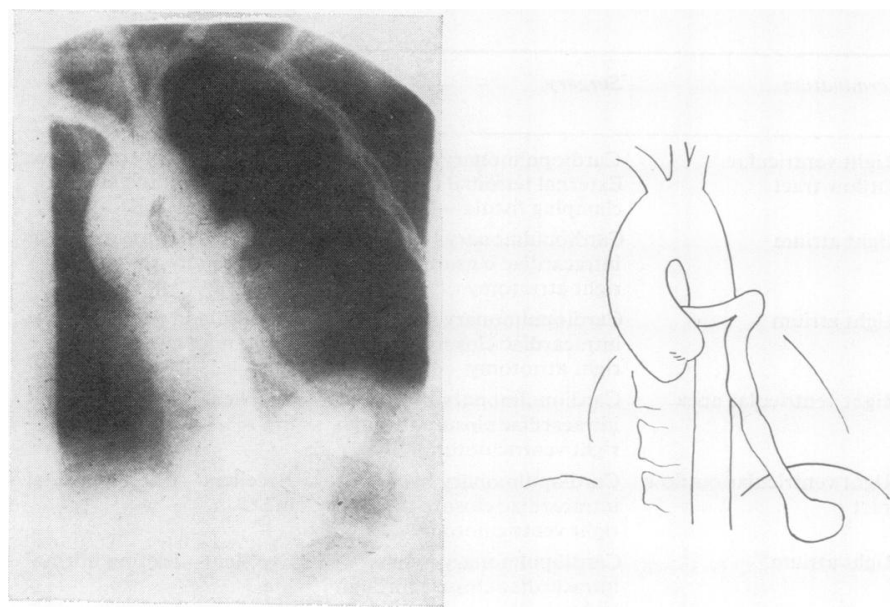

Fig 2 Aortogram in a patient with fistula from left anterior descending branch of left coronary artery opening into the right ventricular apex. The vessel was aneurysmal.

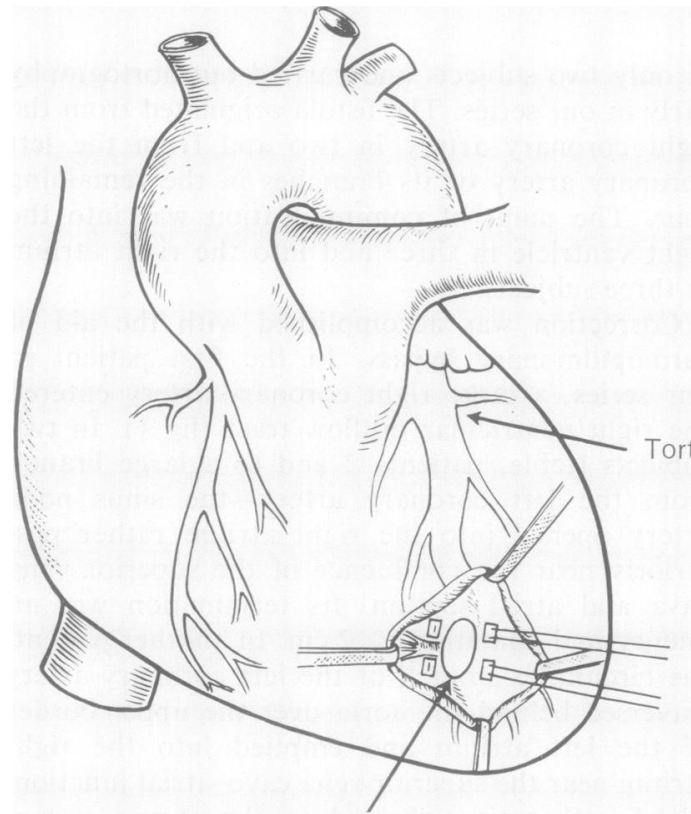

Fig 3 Diagram of intracardiac repair in case 4 papillary muscle detached and reattached and closure by Teflon bolstered suture.

Opening of fistula

right ventriculotomy in two. The fistulous channel was closed with mattress sutures buttressed with Teflon (fig 3).

\section{Results and follow-up}

There was no hospital mortality. All six patients have been followed up for periods ranging from one to seven years. Haemodynamic studies and arteriography in three patients confirmed the closure of the fistula. All the subjects are leading active lives.

\section{Discussion}

Coronary artery fistula is a rare congenital anomaly first reported by $\mathrm{Krause}^{1}$ in 1865 . The incidence varies from $2 \cdot 7-4$ per 1000 population. ${ }^{2} 3$ The great majority of patients are below 20 years of age. Abbott ${ }^{4}$ described the illness and Bjork and Crafoord ${ }^{5}$ reported the continuous murmur associated with this malformation. They closed a coronary artery-pulmonary artery fistula in a 15-year-old boy who was thought before operation to have a patent ductus arteriosus. Fell et al 
were the first to make a correct diagnosis and to obliterate a coronary artery-right ventricular fistula. The right coronary artery is more often involved than the left ${ }^{7}$ and the fistula opens in order of diminishing frequency into the right ventricle, right atrium, pulmonary artery, coronary sinus, and vena cava. The right ventricle was the most common termination in the surgically repaired group. ${ }^{8}$ In the present series, the left coronary artery was involved in four and the right in two subjects. The point of communication was into the right ventricle in three and right atrium in three subjects. The majority of patients with coronary artery fistula are asymptomatic. Symptoms when they do occur are usually secondary to congestive heart failure from a large left to right shunt. Infective endocarditis occurs in about $10 \%$ of patients with coronary artery fistula and is frequently the first manifestation of the cardiac anomaly. ${ }^{9}$ The size of the fistula is said to increase with the passage of time and this may explain the late onset of symptoms in three of our subjects.

The potential complications of this anomaly include congestive cardiac failure, myocardial ischaemia, subacute endocarditis, and pulmonary hypertension. ${ }^{10}$ Massive aneurysm of the involved vessels ${ }^{11}$ and rupture of an aneurysm have been described. ${ }^{12}$ In view of the complications we believe that all patients with congenital coronary artery fistula should have it closed without delay.

Ligation of the involved coronary artery above and below the fistula was an accepted treatment until increasing experience demonstrated that distal ischaemia, ${ }^{4}$ occasionally with myocardial infarction and even ventricular fibrillation, ${ }^{13}$ might result. Furthermore, recurrences can occur after external tangential arteriorrhaphy with mattress sutures placed under the coronary artery. ${ }^{14} 15$ Every attempt should be made to preserve the continuity of the coronary arterial tree. ${ }^{16}$ Although coronary artery fistula has been closed successfully during hypothermic caval occlusion, ${ }^{17}$ cardiopulmonary bypass is preferable. Gasul et $a l^{2}$ have advocated obliteration of the fistula without recourse to bypass. Oldham et al ${ }^{18}$ closed nine out of 12 fistulae without resorting to cardiopulmonary bypass. Nonetheless, we chose to use cardiopulmonary bypass and to perform an intracardiac repair. ${ }^{19} 20$ All patients survived the surgical procedure and had an uneventful recovery. Only in one patient was the fistula closed by external terminal ligation, and even in this one the right ventricular chamber was subsequently opened to ensure that there was no further communication. Cardiopulmonary bypass permits precise closure of the fistula from inside the cardiac chamber without danger of interfering with the coronary arterial flow distally.

We acknowledge gratefully the contribution of Dr Praveenkumar in compiling data and $\mathrm{Mr}$ Nagarajan for secretarial help.

\section{References}

1 Krause W. Ueber den Ursprang einer accessorischen A Coronaira Cordis aus der A Pulmonis. $Z$ Rationalle Med 1865; 24:225-7.

2 Gasul BM, Arcilla RA, Fell EH, Lynfield J, Bicoff P, Luan LL. Congenital coronary arteriovenous fistula. Pediatrics 1960; 25:531-6.

3 Nora JJ, McNamara DG, Fraser FC. Hereditary factors in atrial septal defect. Circulation 1967; 35:448-56.

4 Abbott OA, Rivarola LH, Logue RB. Surgical correction of coronary arteriovenous fistula. $J$ Thorac Cardiovasc Surg 1961; 42:660-72.

5 Björk O, Crafoord C. Arteriovenous aneurysm on the pulmonary artery simulating patent ductus arteriosus Botalli. Thorax 1947; 2:65-8.

6 Fell EH, Weinberg J, Gordon AS, Gasul BM, Johnson FR. Surgery for congenital arteriovenous fistula. Arch Surg 1958; 77:331-5.

7 Perloff JK. The clinical recognition of congenital heart disease. Philadelphia: WB Saunders, 1970: 459.

8 Abrams LD, Evans DW Howarth FH. Coronary artery-right ventricular fistula treated surgically. Br Heart J 1967; 29:132-4.

9 Tsagaris TJ, Hecht HM. Coronary artery aneurysm and sub-acute bacterial endocarditis. Ann Intern Med 1962; 57:116-21.

10 Neill C, Mounsey P. Auscultation in patent ductus arteriosus with a description of two fistulae simulating patent ductus. Br Heart $J$ 1958; 20:61-75.

11 Meyer MH, Stephenson HE, Keats TE, Martt JM. Coronary artery resection for giant aneurysmal enlargement and arteriovenous fistula: a five year follow-up. Am Heart J 1967; 74:60313.

12 Haberman JH, Howard ML, Johnson ES. Rupture of the coronary sinus with hemopericardium. Circulation 1963; 28:1143-4.

13 Hallman GL Cooley DA, Singer DB. Congenital anomalies of coronary arteries. Surgery 1966; 59: 133-8.

14 Meyer J, Reul GJ, Mullins CE et al. Congenital fistulae of the coronary artery. J Cardiovasc Surg 1975; 16:506-11.

15 McNamara JJ, Gross RE. Congenital coronary artery fistula. Discussion by Hallman GL. Surgery 1969; 65:59-69.

16 Cooley DA, Ellis PR. Surgical considerations of coronary arterial fistula. Am J Cardiol 1962; 10: $467-73$. 
17 Swan H, Wilson JN, Woodwark G, Blount SG. Surgical obliteration of a coronary artery fistula into right ventricle. Arch Surg 1959; 79:820-4.

18 Oldham HN Jr, Ebert PA, Young WG. Surgical management of congenital coronary artery fistula. Ann Thorac Surg 1971; 12:503-13.
19 McNamara JJ, Gross RE. Congenital coronary artery fistula. Surgery 1969; 65:59-69.

20 Taber RE, Gale HH, Lam CR. Coronary arteryright heart fistula. J Thorac Cardiovasc Surg 1967; 53:84-92. 